\title{
Antidepressants: mechanism of action, toxicity and possible amelioration
}

\begin{abstract} different categories such as
i. Tricyclic antidepressants (TCAs)
ii. Selective serotonin-reuptake inhibitors (SSRIs)
iii. Monoamine oxidase inhibitors (MAOIs)
iv. Serotonin-norepinephrine reuptake inhibitor (SNRI) and
v. Non-TCA antidepressants based on their mode of action.

Depression being a state of sadness may be defined as a psychoneurotic disorder characterised by mental and functional activity, sadness, reduction in activity, difficulty in thinking, loss of concentration, perturbations in appetite, sleeping, and feelings of dejection, hopelessness and generation of suicidal tendencies. It is a common and recurrent disorder causing significant morbidity and mortality worldwide. The antidepressant compounds used against depression are reported to be used also for treating pain, anxiety syndromes etc. They have been grouped in five

Most of the antidepressants have been reported to possess adverse effects on the health of users. The present review article focuses on an updated current of antidepressants, their mechanism of actions, pathophysiology of these compounds, their side effects and the strategies to combat the drug induced toxicity. An account of phytochemicals found to be acting as antidepressant is also included.

Keywords: depression, antidepressants, toxicity, neurotransmitters, biomarkers
Volume 3 Issue 5 - 2017

\author{
Khushboo, Sharma B \\ Department of Biochemistry, University of Allahabad, India
}

Correspondence: B Sharma, Department of Biochemistry, University of Allahabad, Allahabad 2I I002, UP, India, Email sharmabi@yahoo.com

Received: June 29, 2017 | Published: September 01, 2017
Abbreviations: TCAs, tricyclic antidepressants; SSRIs, selective serotonin-reuptake inhibitors; MAOIs, monoamine oxidase inhibitors; SNRI, serotonin-norepinephrine reuptake inhibitor; PMDD, premenstrual dysphoric disorder; $\mathrm{SAD}$, seasonal affective disorder; PMS, premenstrual syndrome; NE, norepinephrine; 5-HT, 5-hydroxytryptamine; DA, dopamine; CNS, central nervous system; NRI, noradrenalin specific reuptake inhibitor

\section{Introduction}

Depression may be defined in terms of a state of feeling sad. It may also be defined as a psychoneurotic disorder characterised by mental and functional activity, sadness, reduction in activity, difficulty in thinking, loss of concentration, perturbations in appetite, sleeping, and feelings of dejection, hopelessness and generation of suicidal tendencies. ${ }^{1}$ It is a common and recurrent disorder causing significant morbidity and mortality worldwide. ${ }^{2,3}$ Depression, a kind of mental illness, includes arousal of grief which may affect the overall thinking process, behaviour and feelings. ${ }^{1}$ Such persons suffer froman imbalanced sleep and sleeping disorders. ${ }^{4-6}$ Several workers ${ }^{7,8}$ have described the causes of depression which include genetic, heterogeneous parental behaviour to the siblings, neglect and sexual abuse. In addition, certain conditions like difficulties in job, relationships, natural disasters, finances, child birth, catastrophic injury, loss of life of loved ones and menopause. ${ }^{9,10}$ It is known that different brain regions may mediate the onset of variety of symptoms of depression as they regulate emotions, neural circuitry and mood. There is meagre information available about the underlying mechanisms of their regulations. The malfunctioning of the hypothalamus region of the brain has been found to be associated with very less or too much sleep, disinterest in sex and other activities of enjoyment. Depression in general has three main forms such as

i. Psychotic depression characterised by severe depression,

ii. Postpartum depression characterised by perturbations in the levels of hormones and physical features after child birth and

iii. Seasonal Affective Disorder (SAD) concerning specially the winter months with less sunlight. ${ }^{11}$

In the women, the depression arises also due to extra work load, domestic responsibilities, child care, strained relationship, care of aged parents and poverty. In addition to all these indices, the psychological, biological and hormonal factors also significantly contribute in depression. The premenstrual dysphoric disorder (PMDD) or premenstrual syndrome (PMS) and osteoporosis in women can play important role in development of depression. Depression in men may be associated with sufferings from serious diseases such as cancer and cardiac diseases, extreme tiredness, irritation, disinterest in oncepleasurable activities, loss of balance, less sleep and getting aggressive. In older men, arteriosclerotic depression (vascular depression) has been observed. The depression which may lead to suicide in the children may be associated to the emerging sexuality and onset of puberty. The present article is an endeavour to illustrate an updated account and varied aspects of depression such as its pathophysiology, symptoms, diagnosis, treatment with drugs and their mode of actions, toxicity and use of plant products as potential antidepressants. 


\section{Pathophysiology of depression}

There are no useful biomarkers or imaging abnormalities to determine pathophysiology of depression during life time. The postmortem study of brain does not reveal any consistent structural or neurochemical abnormality. Majority of the currently available medications were discovered empirically. Most current theories are based on "amine hypothesis. ${ }^{12}$ " The most important hypothesis of mood disorder is related to the alterations in the levels of biogenic amines. ${ }^{13-15}$ It states that depression is caused by a functional deficiency of catecholamines, particularly norepinephrine (NE), whereas mania is caused by a functional excess of catecholamines at the critical synapses in the brain. The occurrence of depression has been found to be associated with the alterations in the levels of biogenic amines in the brain such as NE, dopamine (DA) and epinephrine, indolamine, serotonin, 5-hydroxytryptamine (5-HT) and two catecholamines.

\section{Antidepressants}

Antidepressants are those drugs which help in the reduction in symptoms of depressive disorders by altering chemical imbalances of neurotransmitters in the brain. The change in mood and behaviour is due to chemical imbalance. Neurotransmitters are the communication link between neurons in the brain. Neurotransmitters are located in vesicles found in nerve cells. The neurotransmitters such as serotonin, dopamine and noradrenaline or norepinephrine are released by the exonic end of one nerve and received by the other; the phenomenon called as reuptake. The antidepressants inhibit reuptake of neurotransmitters through selective receptors thereby increasing the concentration of specific neurotransmitter around the nerves in the brain. One of such antidepressant is selective serotonin Table I Commonly used antidepressants and their mechanisms of actions ${ }^{16}$ reuptake inhibitor (SSRI), which affects the brain serotonin level. Antidepressants may recover the signs of depression, but also exert some side-effects. They are used in the medication of a number of symptoms, including not only depression, some anxiety disorder, nervousness, OCD, manic-depressive disorders, bedwetting in childhood, major depressive disorder, diabetic peripheral neuropathic pain, social fretfulness, post-traumatic stress disorder etc. and some conclude, but not perfect in fibromyalgia, chronic hives (allergic reaction), flashes, drug induced hyperhidrosis (sweating in excess), premenstrual symptoms, pruritus (itching), nervosa, tourette, binge eating disorder etc. The medicines achieve their desired function by adversely influencing the concentrations of neurotransmitters in the brain such as NE, serotonin and dopamine and the central nervous system (CNS). Based on the mode of actions, a group of antidepressants contain 17 substances which can be further divided into subgroups. The commonly used medicines against depression are summarised in Table 1.

\section{Antidepressants and their classification}

Imipramine was discovered in 1958 as an antidepressant regimen. ${ }^{17}$ The antidepressants have been divided into five groups:
i. Tricyclic antidepressants (TCAs),
ii. Selective serotonin-reuptake inhibitors (SSRIs),
iii. Monoamine oxidase inhibitors (MAOIs),
iv. Serotonin-norepinephrine reuptake inhibitor (SNRI) and
v. Non-TCA antidepressants.

\begin{tabular}{|c|c|c|c|c|}
\hline $\begin{array}{l}\text { Sr. } \\
\text { No. }\end{array}$ & ATC-Code & $\begin{array}{l}\text { Name of } \\
\text { substance }\end{array}$ & Pharmaceutical name & Mechanism of action \\
\hline 1 & N06AA04 & Clomipramine & Anafranil- Novartis + generics & Serotonin-norepinephrine reuptake inhibitors \\
\hline 2 & N06AA06 & Trimipramine & Surmontil- sanofiaventis & Serotonin-norepinephrine reuptake inhibitors \\
\hline 3 & N06AA09 & Amitriptyline & Saroten- lundbecktryptizol- msd & Serotonin-norepinephrine reuptake inhibitors \\
\hline 4 & N06AAI0 & Nortriptyline & Sensaval- lundbeck & Serotonin-norepinephrine reuptake inhibitors \\
\hline 5 & N06AA2I & Maprotiline & Ludiomil- Novartis + generics & Serotonin-norepinephrine reuptake inhibitors \\
\hline 6 & N06AB03 & Fluoxetine & Fontex- lilly + generics & Serotonin Reuptake inhibitors \\
\hline 7 & N06AB04 & Citalopram & Cipramil- lundbeck + generics & Serotonin Reuptake inhibitors \\
\hline 8 & N06AB05 & Paroxetine & Seroxat- glaxosk + generics & Serotonin Reuptake inhibitors \\
\hline 9 & N06AB06 & Sertraline & Zoloft-Pfizer + generics & Serotonin Reuptake inhibitors \\
\hline 10 & N06AB08 & Fluvoxamine & Fevarin- solvaypharma & Serotonin Reuptake inhibitors \\
\hline 11 & N06ABIO & Escitalopram & Cipralex- lundbeck & Serotonin Reuptake inhibitors \\
\hline 12 & N06AG02 & Moclobemide & Aurorix- roche + generics & MAO inhibitor \\
\hline
\end{tabular}

The TCAs block the reuptake of both norepinephrine (NE) and serotonin (5HT). This phenomenon being the primary mechanism of actions of antidepressants brings changes in the physiological behaviour of neuro-receptors. TCAs have also been reported to block muscarinic, alpha1 adrenergic and histaminic receptors. However, these molecules may lead to occurrence of different side effects in patients as summarised in Table 2 .

Mourilhe ${ }^{20}$ have reported that the Selective serotonin-reuptake inhibitors (SSRIs) may block the reuptake of 5HT and increase synaptic 5HT transmission. The SSRIs have very little or insignificant effect on the reuptake of other neurotransmitters. It has been observed that SSRIs does not display any activity at the muscarinic and histaminergic receptors which probably results into minute anticholinergic (ACH) and sedative effects (Table 3).

The mechanisms of actions of different antidepressants such as monoamine oxidase inhibitors (MAOIs), phenelzine (Nardil) and tranylcypromine (Parnate) associate with the inhibition of the enzymatic conversion of $5 \mathrm{HT}$ and NE into their corresponding 
metabolites. MAOIs are generally prescribed in cases of atypical or drug resistant depression. These compounds contain a certain level of toxicity. On the contrary to it, the moclobemide (manerix) has been reported to be the first reversible inhibitor of monoamine oxidase A (RIMA). This molecule is found relatively more effective and safe. ${ }^{23}$ Another antidepressant, nefazodone (serzone) has properties of both: it acts like SSRIs which blocks the reuptake of 5HT and also act as an

Table 2 Antidepressants and their side effects antagonist of 5HT2 receptor ${ }^{23}$ thereby reducing the stimulating effects similar to SSRIs. Nefazodone has structural and pharmacological similarities to another antidepressant, trazodone (desyrel). The only difference is that nefazodone binds with $\alpha 1$ receptors with low affinity. All of these antidepressants do not significantly influence $\mathrm{ACH}$ mediated functions (Table 4).

\begin{tabular}{|c|c|c|c|c|c|c|}
\hline $\begin{array}{l}\text { Sr. } \\
\text { No. }\end{array}$ & $\begin{array}{l}\text { Antidepressant } \\
\text { substrate (Common } \\
\text { Name) }\end{array}$ & Doses & $\begin{array}{l}\text { Therapeutic } \\
\text { index (TI) }\end{array}$ & Side-effects & $\begin{array}{l}\text { Toxicity in } \\
\text { overdose }\end{array}$ & References \\
\hline I & Amitriptyline & $\begin{array}{l}\text { start with a dosage of } \\
\text { up to } 100 \mathrm{mg} / \text { day }\end{array}$ & Narrow & $\begin{array}{l}\text { Confusion, Numbness and } \\
\text { Tingling In Your Arms and Legs, } \\
\text { Headache, Constipation Or } \\
\text { Diarrhoea, Blurred Vision, Skin } \\
\text { Rash, Swelling Of Your Face and } \\
\text { Tongue, Nausea, Unexpected } \\
\text { Weight Gain Or Loss }\end{array}$ & High & 18 \\
\hline 2 & Amoxapine & $\begin{array}{l}50 \mathrm{mg}-100 \mathrm{mg} \\
\text { maximum dose: } 600 \\
\text { mg/day }\end{array}$ & Narrow & $\begin{array}{l}\text { Dizziness or light headedness, } \\
\text { confusion, constipation, } \\
\text { difficulty in urinating, dry } \\
\text { mouth }\end{array}$ & - & \\
\hline 4 & Desipramine & $100-300 \mathrm{mg} /$ day & Narrow & $\begin{array}{l}\text { Dizziness or light headedness, } \\
\text { confusion, constipation, } \\
\text { difficulty in urinating, dry } \\
\text { mouth }\end{array}$ & - & \\
\hline 4 & Doxepin & $25-300 \mathrm{mg} /$ day & Narrow & $\begin{array}{l}\text { Dizziness or light headedness, } \\
\text { confusion, constipation, } \\
\text { difficulty in urinating, dry } \\
\text { mouth }\end{array}$ & - & \\
\hline 5 & $\begin{array}{l}\text { Imipramine } \\
\text { Hydrochloride }\end{array}$ & $10-50 \mathrm{mg} /$ day & Narrow & $\begin{array}{l}\text { Dizziness or light headedness, } \\
\text { confusion, constipation, } \\
\text { difficulty in urinating, dry } \\
\text { mouth }\end{array}$ & High & \\
\hline 6 & Imipramine Pamoate & $10-50 \mathrm{mg} / \mathrm{day}$ & Narrow & $\begin{array}{l}\text { Dizziness or light headedness, } \\
\text { confusion, constipation, } \\
\text { difficulty in urinating, dry } \\
\text { mouth }\end{array}$ & High & \\
\hline 7 & Maprotiline & - & Narrow & $\begin{array}{l}\text { Dizziness or light headedness, } \\
\text { confusion, constipation, } \\
\text { difficulty in urinating, dry } \\
\text { mouth }\end{array}$ & - & \\
\hline 8 & Nortriptyline & $10-25 \mathrm{mg} /$ day & Narrow & $\begin{array}{l}\text { Dizziness or light headedness, } \\
\text { confusion, constipation, } \\
\text { difficulty in urinating, dry } \\
\text { mouth }\end{array}$ & High & \\
\hline 9 & Protriptyline & - & Narrow & $\begin{array}{l}\text { Dizziness or light headedness, } \\
\text { confusion, constipation, } \\
\text { difficulty in urinating, dry } \\
\text { mouth }\end{array}$ & - & \\
\hline 10 & Trimipramine & - & Narrow & $\begin{array}{l}\text { Dizziness or light headedness, } \\
\text { confusion, constipation, } \\
\text { difficulty in urinating, dry } \\
\text { mouth }\end{array}$ & High & 19 \\
\hline
\end{tabular}


Table 3 Side effects of use of SSRIs

\begin{tabular}{|c|c|c|c|c|c|c|}
\hline $\begin{array}{l}\text { Sr. } \\
\text { No. }\end{array}$ & $\begin{array}{l}\text { Antidepressant } \\
\text { substrate (Common } \\
\text { Name) }\end{array}$ & Doses & $\begin{array}{l}\text { Therapeutic } \\
\text { index }\end{array}$ & Side-Effects & $\begin{array}{l}\text { Toxicity due } \\
\text { to overdose }\end{array}$ & References \\
\hline I & Citalopram & $\begin{array}{l}20-40 \mathrm{mg} / \\
\text { day }\end{array}$ & Wide & $\begin{array}{l}\text { Nausea,Anxiety, Insomnia Dry Mouth, } \\
\text { Headache, Somnolence, Dizziness, } \\
\text { Agitation, Anorexia, Diarrhoea, } \\
\text { Constipation, Tremor, Sweating, Sexual } \\
\text { Dysfunction }\end{array}$ & Moderate & 21 \\
\hline 2 & Fluoxetine & $\begin{array}{l}10-20 \mathrm{mg} \\
\text { and } 4 \mathrm{mg} / \\
\text { day }\end{array}$ & Wide & $\begin{array}{l}\text { Nausea, Anxiety, Insomnia Dry Mouth, } \\
\text { Headache, Somnolence, Dizziness, } \\
\text { Agitation, Anorexia, Diarrhoea, } \\
\text { Constipation, Tremor, Sweating, Sexual } \\
\text { Dysfunction }\end{array}$ & Low & 22 \\
\hline 3 & Fluvoxamine & $\begin{array}{l}50-100 \mathrm{mg} / \\
\text { day }\end{array}$ & Wide & $\begin{array}{l}\text { Nausea ,Anxiety, Insomnia Dry Mouth, } \\
\text { Headache, Somnolence, Dizziness, } \\
\text { Agitation, Anorexia, Diarrhoea, } \\
\text { Constipation, Tremor, Sweating, Sexual } \\
\text { Dysfunction }\end{array}$ & Low & 22 \\
\hline 4 & Paroxetine & $\begin{array}{l}20-30 \mathrm{mg} / \\
\text { day }\end{array}$ & Wide & $\begin{array}{l}\text { Nausea,Anxiety, Insomnia, Dry Mouth, } \\
\text { Headache, Somnolence, Dizziness, } \\
\text { Agitation, Anorexia, Diarrhoea, } \\
\text { Constipation, Tremor, Sweating, Sexual } \\
\text { Dysfunction }\end{array}$ & Low & 22 \\
\hline 5 & Sertraline & $\begin{array}{l}25-100 \mathrm{mg} / \\
\text { day }\end{array}$ & Wide & $\begin{array}{l}\text { Nausea ,Anxiety, Insomnia Dry Mouth, } \\
\text { Headache, Somnolence, Dizziness, } \\
\text { Agitation, Anorexia, Diarrhoea, } \\
\text { Constipation, Tremor, Sweating, Sexual } \\
\text { Dysfunction }\end{array}$ & Low & 22 \\
\hline 6 & Nefazodone & $\begin{array}{l}100-200 \mathrm{mg} / \\
\text { day }\end{array}$ & Wide & $\begin{array}{l}\text { Nausea ,Anxiety, Insomnia Dry Mouth, } \\
\text { Headache, Somnolence Dizziness } \\
\text { Agitation Anorexia, Diarrhoea, } \\
\text { Constipation, Tremor, Sweating, Sexual } \\
\text { Dysfunction }\end{array}$ & - & 22 \\
\hline 7 & Trazodone & $\begin{array}{l}50-100 \mathrm{mg} / \\
\text { day }\end{array}$ & Wide & $\begin{array}{l}\text { Nausea ,Anxiety, Insomnia Dry Mouth, } \\
\text { Headache, Somnolence Dizziness } \\
\text { Agitation Anorexia, Diarrhoea, } \\
\text { Constipation, Tremor, Sweating, Sexual } \\
\text { Dysfunction }\end{array}$ & - & 22 \\
\hline
\end{tabular}

The activity of serotonin nor-epinephrine reuptake inhibitors (SNRIs) does not exert any side effects such as sedation or hypotension but display TCAs like activity. ${ }^{23}$ Higher doses of SNRIs have been reported to mildly increase blood pressure. The above mentioned antidepressants in adequate dosages exhibit same level of effects for treatment of depression. Some of the SNRIs are duloxetine (Cymbalta), venlafaxine (Effexor XR), desvenlafaxine (Pristiq, Khedezla) and levomilnacipran (Fetzima). The first line of antidepressants is the Non-TCAs (NTCA) which includes SSRIs. These agents are relative safer with better tolerability. Those patients which do not show any response to other drugs or suffering from chronic pain or migraine are given TCAs. However, the existing reports suggest that the secondary amine TCAs (desipramine and nortriptyline) possess more side effects than tertiary amine TCAs (Table 5). A comparative estimate of antidepressants and their therapeutic properties are summarised in Table 6.

\section{Interaction of antidepressants with the cellular recep- tors}

As explained above, the MAOIs block the metabolism of neurotransmitters such as NE, DA and 5-HT and cause increase in the concentration of monoamine transmitters. The traditional MAOIs (tranylcypromine) act in irreversible and non-selective manner whereas the recently investigated MAOIs are reversible in binding and very selective for MAO-A or MAO-B. TCAs is a combo drug ${ }^{30}$ containing at least five chemical agents with different activities such as a serotonin reuptake inhibitor activity, a norepinephrine reuptake inhibitor activity, an anti-cholinergic anti-muscarinic activity, an alfa 1adrenergic antagonist activity, and an antihistamine (H1) activity. ${ }^{31}$ When taken in overdose, they cause toxicity in terms of lethal cardiac arrhythmias and seizures. The mechanism of action of TCAs relies on the inhibition of reuptake of serotonin and NE. ${ }^{31}$ The different 
members of TCAs display differential inhibition activity on 5HT and NE transporters. Clomipramine has been reported to be the most potent at 5-HT reuptake pump whereas desipramine and maprotiline

Table 4 Doses and side effects of some other antidepressants were more potent at NE reuptake pump. The drug toxicity of TCAs has been explained in terms of their effects on certain receptors such as $\mathrm{H} 1, \mathrm{M} 1$, and alfa1.

\begin{tabular}{|c|c|c|c|c|c|c|}
\hline $\begin{array}{l}\text { Sr. } \\
\text { No. }\end{array}$ & $\begin{array}{l}\text { Antidepressant } \\
\text { substrate (Common } \\
\text { Name) }\end{array}$ & Doses & $\begin{array}{l}\text { Therapeutic } \\
\text { index }\end{array}$ & Side-effects & $\begin{array}{l}\text { Toxicity in } \\
\text { overdose }\end{array}$ & References \\
\hline I & Isocarboxazid & $\begin{array}{l}40-60 \mathrm{mg} / \\
\text { day }\end{array}$ & Wide & $\begin{array}{l}\text { Dizziness, Headache, Tremors Or } \\
\text { Shaking; Constipation, Nausea; Or Dry } \\
\text { Mouth. }\end{array}$ & High & 24 \\
\hline 2 & Phenelzine & $60 \mathrm{mg} /$ day & Wide & $\begin{array}{l}\text { Dizziness, Headache, Drowsiness, Sleep } \\
\text { Disturbances (Including Insomnia, } \\
\text { Hypersomnia), Fatigue,Weakness, } \\
\text { Tremors, Twitching, Myoclonic } \\
\text { Movements, Hyperreflexia }\end{array}$ & High & 25 \\
\hline 3 & Tranylcypromine & $60 \mathrm{mg} /$ day & Wide & $\begin{array}{l}\text { Scleroderma, Flare-Up Of Cystic Acne, } \\
\text { Ataxia, Confusion, Disorientation, } \\
\text { Memory Loss, Urinary Frequency, } \\
\text { Urinary Incontinence, Urticaria, Fissuring } \\
\text { In Corner Of Mouth, Akinesia }\end{array}$ & Low & 26 \\
\hline 4 & Moclobemide & $300 \mathrm{mg} /$ day & Wide & $\begin{array}{l}\text { Nausea, Dry Mouth, Constipation, } \\
\text { Diarrhoea, Anxiety, Restlessness, } \\
\text { Insomnia, Dizziness }\end{array}$ & High & 27 \\
\hline
\end{tabular}

Table 5 Doses and adverse effects of application of Non-TCA (NTCA) antidepressants

\begin{tabular}{|c|c|c|c|c|c|c|}
\hline $\begin{array}{l}\text { Sr. } \\
\text { No. }\end{array}$ & $\begin{array}{l}\text { Antidepressant } \\
\text { substrate } \\
\text { (Common } \\
\text { Name) }\end{array}$ & Doses & $\begin{array}{l}\text { Therapeutic } \\
\text { index }\end{array}$ & Side-effects & $\begin{array}{l}\text { Toxicity in } \\
\text { overdose }\end{array}$ & References \\
\hline I & Agomelatine & $25-50 \mathrm{mg} /$ day & Narrow & $\begin{array}{l}\text { Dizziness Abnormal Changes In Liver } \\
\text { Function Tests Abdominal Pain }\end{array}$ & Unclear & 22 \\
\hline 2 & Bupropion & 150 mg/day & Narrow & $\begin{array}{l}\text { Insomnia, Nausea, Pharyngitis, Weight } \\
\text { Loss, Constipation, Dizziness, Headache, } \\
\text { And Xerostomia }\end{array}$ & Moderate & \\
\hline 3 & Duloxetine & $60 \mathrm{mg} /$ day & Wide & $\begin{array}{l}\text { Asthenia, Constipation, Diarrhea, } \\
\text { Dizziness, Drowsiness, Fatigue, } \\
\text { Hypersomnia, Insomnia, Nausea, Sedation, } \\
\text { Headache, and Xerostomia. }\end{array}$ & Moderate & \\
\hline 4 & Mianserin & $30-200 \mathrm{mg} /$ day & Narrow & $\begin{array}{l}\text { Drowsiness, Liver Dysfunction, Jaundice, } \\
\text { Gynaecomastia, Convulsions, Hypomania, } \\
\text { Hypotension, Hypertension; Coma, } \\
\text { Arthralgia, Oedema, Tachycardia, } \\
\text { Bradycardia,Vomiting, Dizziness and } \\
\text { Ataxia,Anti-cholinergic Effects }\end{array}$ & Low & \\
\hline 5 & Reboxetine & 8mg/Day & Narrow & $\begin{array}{l}\text { Urinating problem, Dry Mouth, Sweating, } \\
\text { Tingling or Numbness of The Hands } \\
\text { or Feet, Constipation, Increase in } \\
\text { Blood Pressure, Increase in Heart } \\
\text { Rate, Impotence, Insomnia, Headache, } \\
\text { Dizziness, Nausea, Decreased Appetite }\end{array}$ & Low & \\
\hline
\end{tabular}


Table Continued.

\begin{tabular}{|c|c|c|c|c|c|c|}
\hline $\begin{array}{l}\text { Sr. } \\
\text { No. }\end{array}$ & $\begin{array}{l}\text { Antidepressant } \\
\text { substrate } \\
\text { (Common } \\
\text { Name) }\end{array}$ & Doses & $\begin{array}{l}\text { Therapeutic } \\
\text { index }\end{array}$ & Side-effects & $\begin{array}{l}\text { Toxicity in } \\
\text { overdose }\end{array}$ & References \\
\hline 6 & Trazodone & $150-400 \mathrm{mg} /$ day & Wide & $\begin{array}{l}\text { Blurred vision, Dizziness, Drowsiness, } \\
\text { Headache, Nausea, Vomiting, and } \\
\text { Xerostomia Syncope, Edema, Ataxia, } \\
\text { Confusion, Diarrhea, Hypotension, } \\
\text { Insomnia, Sedation, and Tachycardia }\end{array}$ & Low & \\
\hline 7 & Venlafaxine & $\begin{array}{l}75 \mathrm{mg} / \text { day with } \\
\text { Food ( } 37.5 \mathrm{mg} / \\
\text { day if Anxious or } \\
\text { Debilitated) }\end{array}$ & Narrow & $\begin{array}{l}\text { Bipolar Disorder (Manic Depression); } \\
\text { Cirrhosis Or Other Liver Disease, Kidney } \\
\text { Disease, Heart Disease, High Blood } \\
\text { Pressure, High Cholesterol, Diabetes; } \\
\text { Narrow-Angle Glaucoma, A Thyroid } \\
\text { Disorder, A History of Seizures, A } \\
\text { Bleeding or Blood Clotting Disorder, Low } \\
\text { Levels of Sodium in Your Blood }\end{array}$ & Moderate & \\
\hline
\end{tabular}

Table 6 A comparative estimate of antidepressants and their therapeutic properties. ${ }^{28,29}$

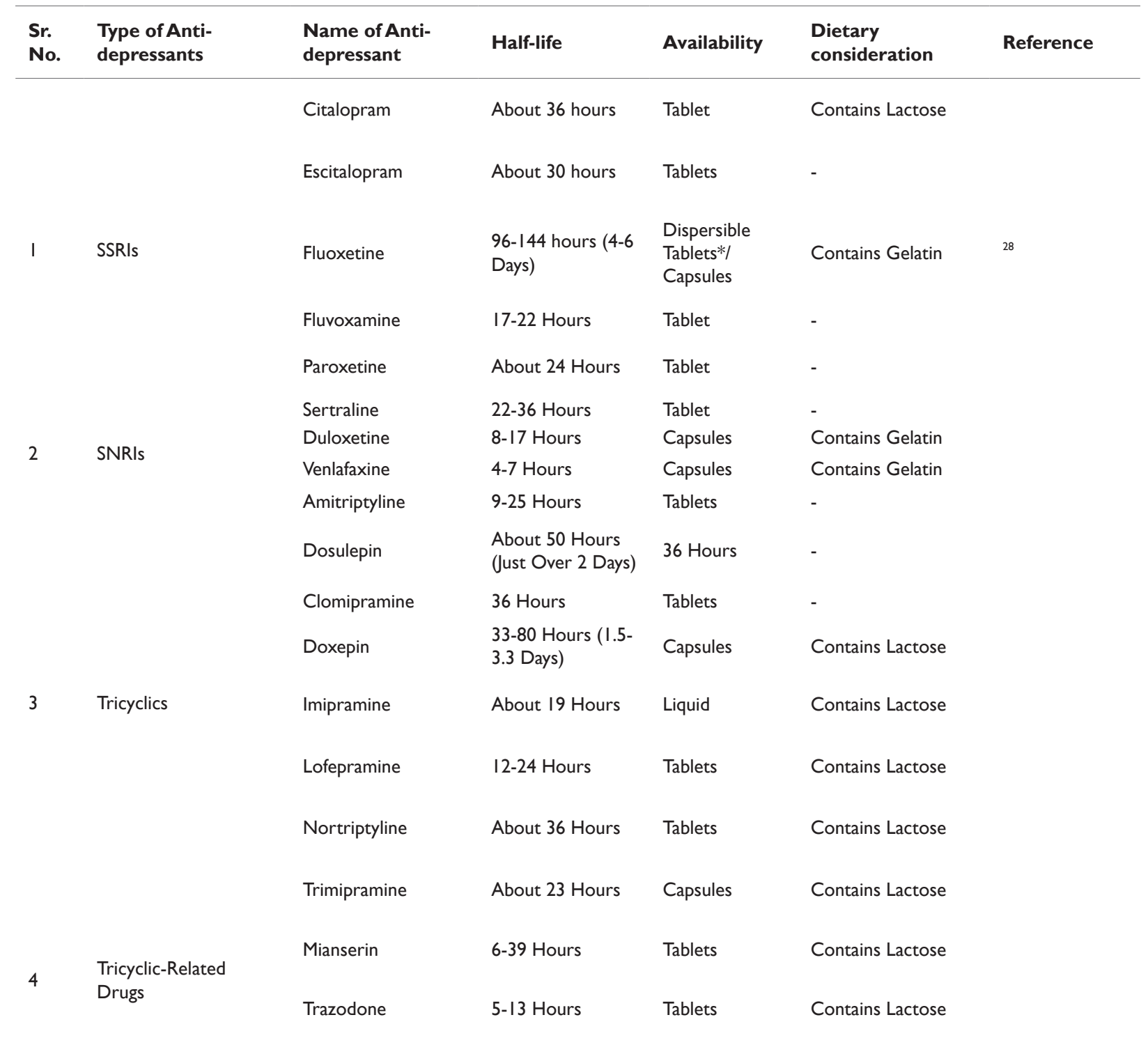


Table Continued...

\begin{tabular}{|c|c|c|c|c|c|c|}
\hline $\begin{array}{l}\text { Sr. } \\
\text { No. }\end{array}$ & $\begin{array}{l}\text { Type of Anti- } \\
\text { depressants }\end{array}$ & $\begin{array}{l}\text { Name of Anti- } \\
\text { depressant }\end{array}$ & Half-life & Availability & $\begin{array}{l}\text { Dietary } \\
\text { consideration }\end{array}$ & Reference \\
\hline \multirow{4}{*}{5} & \multirow{4}{*}{ MAOls } & Isocarboxazid & About 36 Hours & Tablets & Contains Lactose & \\
\hline & & Phenelzine & II-I2 Hours & Tablets & $\begin{array}{l}\text { Requires Food } \\
\text { Restrictions }\end{array}$ & \\
\hline & & Moclobemide & 2-4 Hours & Tablets & $\begin{array}{l}\text { Requires Food } \\
\text { Restrictions }\end{array}$ & \\
\hline & & Tranylcypromine & About 2 Hours & Tablets & $\begin{array}{l}\text { Requires Food } \\
\text { Restrictions }\end{array}$ & \\
\hline \multirow{5}{*}{6} & \multirow{5}{*}{ Others } & Agomelatine & I-2 Hours & Tablets & Contains Lactose & \\
\hline & & Mirtazapine & $20-40$ Hours & Liquid & - & \\
\hline & & Reboxetine & About I 3 Hours & Tablets & - & \\
\hline & & Triptafen & N/A & Tablets & - & \\
\hline & & Vortioxetine & About 66 Hours & Tablets & - & \\
\hline
\end{tabular}

*Dispersible tablets will disintegrate quickly in the mouth or can be mixed with water, orange juice or apple juice.

*All other antidepressants currently available do not contain lactose or gelatin, and do not require any specific dietary restrictions, although caution when drinking alcohol is a recommended for all antidepressants.

\section{Selective serotonin reuptake inhibitors (SSRIs)}

SSRIs are known to selectively inhibit serotonin transport. Some of the SSRIs are fluoxetine (Prozac, Selfemra), paroxetine (Paxil, Pexeva), sertraline (Zoloft), citalopram (Celexa) and escitalopram (Lexapro). This action of SSRIs results into abrupt increase in serotonin in the somatodendritic area of serotonergic neurons which causes desensitization of the somatodendritic serotonin-1A autoreceptors..$^{3-33}$ As a result, the neuronal impulse flow is increased..$^{33}$ It causes increased release of serotonin from axon terminals, which culminates into desensitization of postsynaptic serotonin receptors. Desensitization of these receptors may contribute to the therapeutic actions of SSRIs or it could account for the development of tolerance to acute side effects of SSRIs. The pharmacological analysis of SSRIs suggests that these agents may cause strong but slow disinhibition of 5-HT neurotransmission in the central nervous system (CNS). In this case, the actions of antidepressants are mediated by a pathway from midbrain raphe to prefrontal cortex. ${ }^{34,35}$ The side effects generated by SSRIs include anxiety, sleep disturbances, sexual dysfunction (decreased libido, reduced pleasurability and reduction in arousal), and gastrointestinal disturbances. ${ }^{30}$ It is thought that the toxicity the 5-HT2 and 5-HT3 receptors of certain serotonergic pathways are responsible. A reciprocal relationship exists between serotonin and dopamine viz. serotonin tending to inhibit sexual functioning and dopamine tending to enhance sexual functioning. It is believed that serotonin pathway descending from brain stem down the spinal cord to spinal neurons that mediate various spinal reflexes is responsible for the sexual dysfunction in the form of ejaculation and orgasm problems. It has been reported that the enhanced serotonergic flow through this pathway inhibits sexual functioning. The serotonin's negative effects on sexual functioning are mediated via 5-HT2 receptors. Therefore 5-HT2 antagonists can reverse SSRIs induced sexual dysfunction. ${ }^{36,37}$

\section{The antidepressant acting as serotonin/norepinephri- ne/dopamine reuptake inhibitor (SNRI)}

Stahl ${ }^{30}$ have demonstrated the pharmacologic effect of venlafaxine and found it to be dose dependent. At low doses, it essentially acts as an SSRI and at medium to high doses, it causes additional NE reuptake inhibition and at very high doses, DA reuptake inhibition occurs. ${ }^{30,39}$ Other antidepressants such as nefazodone and trazodone act via serotonin-2 receptor antagonism with serotonin reuptake blockade. It is interesting to mention here that SSRIs stimulate 5-HT2 receptors where as nefazodone and trazodone blocks the receptor. ${ }^{30}$ This action of nefazodone and trazodone makes it safer antidepressants than the SSRIs.

\section{Depressants as norepinephrine and dopamine reup- take inhibitor (Bupropion)}

Bupropion is the only antidepressant that selectively acts on the noradrenergic and dopaminergic systems and not on the serotonin system. ${ }^{40}$ Bupropion exhibits dopaminergic and noradrenergic activity, therefore it may exert positive effect in overcoming the attention deficit disorder ${ }^{41}$ and in the treatment of smoking cessation. ${ }^{38}$ In contrary to the benefits from this drug, bupropion has been shown to induce some side effects such as overstimulation, agitation, insomnia and nausea. ${ }^{30,39}$

\section{Antidepressants showing $\alpha-2$ antagonism plus seroto- nin-2 and serotonin-3 antagonism}

Mirtazapin, a noradrenergic and specific serotonergic antidepressant, ${ }^{43}$ has both pro-adrenergic and proserotonergic actions. The pro-adrenergic and proserotonergic actions of mirtazapin are due to its alpha2-antagonist properties i.e. disinhibition of both serotonin and norepinephrine neurotransmission. Similar to nefazodone, mirtazapine also does not exert any toxicity of SSRIs due to 5-HT2 stimulation. Since strong antihistamine properties are associated to mirtazapin, it has some side effects such as weight gain and sedation. ${ }^{30,39}$

\section{The antidepressants acting as a noradrenalin specific reuptake inhibitor (NRI) (Reboxetine)}

Reboxetine, a noradrenaline (norepinephrine) reuptake inhibitor, is exclusively unrelated to TCA or SSRIs. The specific properties of 
reboxetine includes its high affinity for the noradrenaline transporter, and little affinity for other neuro receptors including serotonin, dopamine, histamine, muscarinergic and alpha adrenergic sites. ${ }^{43}$

\section{Antidepressants as a serotonin reuptake enhancer (Tianeptine)}

Tianeptine being, a tricyclic compound of dibenzothiazepine type increases the presynaptic uptake of serotonin after single as well as repeated administration, but this action is not linked to any effects on the 5-HT post-synaptic systems..$^{50,89}$ Tianeptine has no affinity for alfa1 adrenergic and $\mathrm{H} 1$ antihistaminic receptors. Tianeptine can be considered as the mid-position antidepressants. Defrance et al ${ }^{45}$ have shown that tianeptine does not show any affinity for the muscarinic receptors. Tianeptine has been reported to exert little toxicity such as gastralgia, abdominal pain, dry mouth, anorexia, nausea, vomiting, flatulence, insomnia, drowsiness, nightmares, asthenia, and tachycardia in certain patients ${ }^{44-46}$

\section{Phytochemicals as antidepressants}

Some phytochemicals are reported to act as antidepressants. These chemicals present in the plant extracts are expected to be safer and more cost effective than the existing antidepressants. Different ethnopharmaceutical properties of various plant extracts and their effects are summarised in Table 7.

Table 7 Phytochemicals acting as natural antidepressants

\begin{tabular}{|c|c|c|c|c|c|}
\hline Plant Extract & $\begin{array}{l}\text { Common } \\
\text { name }\end{array}$ & $\begin{array}{l}\text { Part used } \\
\text { from the plant }\end{array}$ & $\begin{array}{l}\text { Type of extract, } \\
\text { compound, doses }\end{array}$ & Effects & References \\
\hline Allium macrostemon & Chinese Garlic & Bulb & Water Extracts & & 47 \\
\hline Allium sativum & Garlic & Rhizome & $\begin{array}{l}\text { Ethanolic Extract, dose- } \\
25,50 \text { and } 100 \mathrm{mg} / \mathrm{kg}\end{array}$ & Behavioural Despair & 48 \\
\hline Aloysia polystachya & Lemon Verbena & Aerial Part & Hydroethanolic Extract & Effect on Depression & 49 \\
\hline Apocynum venetum & Dogbane & Aerial Part & Dose- $30-125 \mathrm{mg} / \mathrm{kg}$ & Effect on Depression & 50 \\
\hline Areca catechu & Betel Nut & Fruit & $\begin{array}{l}\text { Ethanolic Extract, dose- } \\
4-80 \mathrm{mg} / \mathrm{kg}\end{array}$ & Effect on Motor Activity & 51 \\
\hline Asparagus racemosus & Satavari & Root & $\begin{array}{l}\text { Methanolic Extract, dose- } \\
100,200 \text { and } 400 \mathrm{mg} / \mathrm{kg}\end{array}$ & $\begin{array}{l}\text { Effect on Serotonergic And } \\
\text { Noradrenergic System And } \\
\text { Augmentation Of Antioxidant } \\
\text { Defences }\end{array}$ & 52 \\
\hline Bacoba monnieri & Brahmi & Aerial Part & $\begin{array}{l}\text { Methanolic Extract, dose- } \\
20 \text { and } 40 \mathrm{mg} / \mathrm{kg}\end{array}$ & $\begin{array}{l}\text { Significant Antioxidant Effect, } \\
\text { Anxiolytic Activity And Improve } \\
\text { Memory Retention }\end{array}$ & 53 \\
\hline Berberis aristata & Indian Barberry & Root & $\begin{array}{l}\text { Berberine, (An Alkaloid), } \\
\text { dose-5, } 10 \text { and } 20 \mathrm{mg} / \mathrm{kg} \text {. }\end{array}$ & $\begin{array}{l}\text { Effect on CNS, Inhibit Monoamine } \\
\text { Oxidase-A }\end{array}$ & 54 \\
\hline Bupleurum falcatum & $\begin{array}{l}\text { Chai Hu, Hare's } \\
\text { Ear Root }\end{array}$ & Root & Methanolic Extract & Psycho stimulant Effect & 55 \\
\hline Cimicifuga racemosa & Black Bugbane & $\begin{array}{l}\text { Roots And } \\
\text { Rhizomes }\end{array}$ & $\begin{array}{l}\text { Ethanolic And } \\
\text { Isopropanolic Aqueous } \\
\text { Extracts }\end{array}$ & $\begin{array}{l}\text { Effect on heraprutical Responses In } \\
\text { Climacteric Women }\end{array}$ & 56 \\
\hline Clitoria ternatea & Butterfly Pea & Root ,Bark & $\begin{array}{l}\text { Ethanolic Extract, } 50 \text { or } \\
100 \mathrm{mg} / \mathrm{kg}\end{array}$ & $\begin{array}{l}\text { Effect on Cognitive Behaviour, } \\
\text { Anxiety, Depression, Stress }\end{array}$ & 57 \\
\hline Crocus sativus & Saffron & Stigma & Ethanolic Extract & Effect on Depression & 58 \\
\hline Curcuma longa & Turmeric & Rhizome & $\begin{array}{l}\text { Aqueous Extract, dose- } \\
\text { 140-560mg/kg for } 14 \text { days. }\end{array}$ & Mao Inhibition In Brain & 59 \\
\hline Emblica officinalis & Amla & Fruit & - & Effect on Psychiatric Disorder & 60 \\
\hline Ginkgo biloba & $\begin{array}{l}\text { Ginkgo, } \\
\text { Maidenhair Tree }\end{array}$ & Leaves & $\begin{array}{l}\text { Lipophilic Extract, dose- } 50 \\
\text { and } 100 \mathrm{mg} / \mathrm{kg}\end{array}$ & $\begin{array}{l}\text { Act As Anti-Stress and } \\
\text { Antidepressant }\end{array}$ & 61 \\
\hline Glycyrrhiza uralensis & Mulethi & Root & Liquiritin (Flavones) & $\begin{array}{l}\text { Antidepressant Like and Antioxidant } \\
\text { Activity By Measuring Erythrocyte } \\
\text { Superoxide Dismutase (Sod) Activity } \\
\text { And Plasma Malondialdehyde (MDA) } \\
\text { Level }\end{array}$ & 62 \\
\hline Glycyrrhiza glabra & Mulethi & Root & $\begin{array}{l}\text { Aqueous Extract, Liquorice } \\
\text { Extract }\end{array}$ & Effect on Inhibition Of Mao & 63 \\
\hline
\end{tabular}


Table Continued..

\begin{tabular}{|c|c|c|c|c|c|}
\hline Plant Extract & $\begin{array}{l}\text { Common } \\
\text { name }\end{array}$ & $\begin{array}{l}\text { Part used } \\
\text { from the plant }\end{array}$ & $\begin{array}{l}\text { Type of extract, } \\
\text { compound, doses }\end{array}$ & Effects & References \\
\hline Hippeastrum vittatum & Amaryllis & Flower & Alkaloids & $\begin{array}{l}\text { Effect on Neurological Disorders } \\
\text { And Neuro degenerative Disease }\end{array}$ & 64 \\
\hline $\begin{array}{l}\text { Hypericum } \\
\text { canariensel. } \\
\text { And Hypericum } \\
\text { glandulosum }\end{array}$ & $\begin{array}{l}\text { Canary Island St } \\
\text { John Wort }\end{array}$ & Aerial Part & Methanolic Extract & $\begin{array}{l}\text { Neuro pharmacological Effect, } \\
\text { Helps In Muscle Relaxation, Anti- } \\
\text { cholinergic And Sedative Properties }\end{array}$ & 65 \\
\hline Hypericum reflexum & Hypericum & Aerial Part & Methanolic Extract & Effect on CNS & 66 \\
\hline Kaempferia parviflora & Kava Kava & $\begin{array}{l}\text { Kava Root/ } \\
\text { Rhizome }\end{array}$ & Rhizome Extract & Effect on Psychiatric Illness & 67 \\
\hline Lafoensia pacari & Didal & Leaves & - & Effects on CNS & 68 \\
\hline $\begin{array}{l}\text { Magnolia bark and } \\
\text { ginger rhizome }\end{array}$ & Magnolia, Ginger & Bark, Rhizome & $\begin{array}{l}\text { Honokiol and Magnolol, } \\
\text { Polysaccharides }\end{array}$ & Effect on Synergistic Interaction & 69 \\
\hline Marsilea minuta & $\begin{array}{l}\text { Dwarf Water } \\
\text { Clover }\end{array}$ & Root & $\begin{array}{l}\text { Marsiline, Sedative And } \\
\text { Anticonvulsant Property }\end{array}$ & $\begin{array}{l}\text { Effect on Insomnia And Other } \\
\text { Mental Disorders }\end{array}$ & 70 \\
\hline Mimosa pudica & Sensitive Plant & Leave & Aqueous Extract & Act As Tricyclic Antidepressants & 71 \\
\hline Mitragyna speciosa & Kratom & Leaves & $\begin{array}{l}\text { Mitragynine An Active } \\
\text { Alkaloid }\end{array}$ & $\begin{array}{l}\text { Effect on Diarrhea, Diabetes And } \\
\text { Improve Blood Circulation }\end{array}$ & 72 \\
\hline Momordica charantia & $\begin{array}{l}\text { Bitter Gourd/ } \\
\text { Bitter Melon }\end{array}$ & Fruit & $\begin{array}{l}\text { Methanol Extract, dose- } \\
300 \mathrm{mg} / \mathrm{kg}\end{array}$ & & 73 \\
\hline Morinda officinalis & Indian Mulberry & Root & Dose- $25-50 \mathrm{mg} / \mathrm{kg}$ & Effective In Response Rate & 74 \\
\hline Oscimum sanctum & Tulsi & Aerial Part & & & 75 \\
\hline Paeonia lactiflora pall & Garden Peony & Root & $\begin{array}{l}\text { Ethanolic extract, dose- } \\
250 \text { and } 500 \mathrm{mg} / \mathrm{kg}\end{array}$ & $\begin{array}{l}\text { Effect on Central Monoaminergic } \\
\text { Neurotransmitter System }\end{array}$ & 76 \\
\hline Piper tuberculatum & Black Pepper & Fruit & $\begin{array}{l}\text { Piplartine (An Amide), } \\
\text { dose- } 50 \text { and } 100 \mathrm{mg} / \mathrm{kg}\end{array}$ & $\begin{array}{l}\text { Effect on Anxiolytic And } \\
\text { Antidepressant Activities, Anxiety } \\
\text { And Depression. }\end{array}$ & 78 \\
\hline Polygala sabulosa & Polygala & Aerial Part & Scopoletin, A Coumarin & $\begin{array}{l}\text { Effect on Serotonergic, } \\
\text { Dopaminergic And Noradrenergic } \\
\text { Systems }\end{array}$ & 79 \\
\hline Rhazyastricta & White Henna & Leaves & Aqueous Extract & $\begin{array}{l}\text { Effect on Monoamine Oxidase } \\
\text { Inhibition }\end{array}$ & 80 \\
\hline Rosmarinusofficinalis & Rosemary & Fresh Juice & Hydro-alcoholic Extract & $\begin{array}{l}\text { Interaction With The } \\
\text { Monoaminergic System }\end{array}$ & 81 \\
\hline Salvia elegans & Pineapple Sage & Leave & Hydroalcoholic Extract & Putative Anxiolytic & 82 \\
\hline Schinusmolle L & $\begin{array}{l}\text { Peruvian Pepper } \\
\text { Tree }\end{array}$ & Leaves & Hexenic Extract & $\begin{array}{l}\text { Pharmacological Effects, atleast At A } \\
\text { Preclinical Level }\end{array}$ & 83 \\
\hline $\begin{array}{l}\text { Siphocampylus } \\
\text { verticillatus }\end{array}$ & Siphocampylus & Aerial Parts & $\begin{array}{l}\text { Hydroalcoholic Extract, } \\
\text { dose range-100-1000mg/kg }\end{array}$ & $\begin{array}{l}\text { Interaction With Adrenergic, } \\
\text { Dopaminergic, Glutamatergic And } \\
\text { Serotonergic System }\end{array}$ & 84 \\
\hline Sphaeranthu sindicus & $\begin{array}{l}\text { East Indian Globe } \\
\text { Thistle }\end{array}$ & Whole Part & Hydroalcoholic Extract & $\begin{array}{l}\text { Effect On Anxiety, Depression And } \\
\text { Convulsions }\end{array}$ & 85 \\
\hline Tabebuia avellaneda & $\begin{array}{l}\text { Lapacho, Taheboo } \\
\text { Tree }\end{array}$ & Bark & Ethanolic Extract & $\begin{array}{l}\text { Effect Of The Association Of The } \\
\text { Extract With The Antidepressants }\end{array}$ & [86] \\
\hline
\end{tabular}


Table Continued..

\begin{tabular}{|c|c|c|c|c|c|}
\hline Plant Extract & $\begin{array}{l}\text { Common } \\
\text { name }\end{array}$ & $\begin{array}{l}\text { Part used } \\
\text { from the plant }\end{array}$ & $\begin{array}{l}\text { Type of extract, } \\
\text { compound, doses }\end{array}$ & Effects & References \\
\hline Tagetes lucida & Marigolds & Aerial Part & - & Effect On CNS & 87 \\
\hline Tinospora cardifolia & Guduchi & Whole Part & $\begin{array}{l}\text { Petroleum Ether Extract, } \\
\text { dose- } 50,100 \text { and } 200 \mathrm{mg} / \\
\mathrm{kg} .\end{array}$ & Effect on Mao-A and Mao-B & 48 \\
\hline Valeriana officinalis & Valerian & Root & Ethanolic Extract & $\begin{array}{l}\text { Effect on Mild Sleep Disorders and } \\
\text { Nervous Tension }\end{array}$ & 48 \\
\hline Valeriana wallichi & Indian Valeriana & Root Bark & $\begin{array}{l}\text { Methanolic and Aqueous } \\
\text { Extract }\end{array}$ & & 89 \\
\hline Withania somnifera & Ashwagandha & Aerial Part & $\begin{array}{l}\text { Bioactive Glyco } \\
\text { withanolides }\end{array}$ & $\begin{array}{l}\text { Effect on Anxiolytic And } \\
\text { Antidepressant Action }\end{array}$ & 90 \\
\hline
\end{tabular}

\section{Conclusion}

Depression is a serious psychological condition but it can be effectively treated with available therapies. The stock of antidepressants available may be selectively used for treating depression safely without any side effects. The right medication to an individual depends on the clinico-physiological conditions of the patient such as symptoms, possible side effects, and interaction with other medications, state of pregnancy or breast feeding and the mental conditions. Different classes of antidepressants are in practice depending on the type and requirement of depression. Antidepressants include selective serotonin reuptake inhibitors (SSRIs), Serotonin and norepinephrine reuptake inhibitors (SNRIs), Norepinephrine and dopamine reuptake inhibitors (NDRIs: Bupropion (Wellbutrin, Aplenzin, Forfivo XL), Atypical antidepressants (trazodone (Oleptro), mirtazapine (Remeron) and vortioxetine (Brintellix)), Tricyclic antidepressants (imipramine (Tofranil), nortriptyline (Pamelor), amitriptyline, doxepin, trimipramine (Surmontil), desipramine (Norpramin) and protriptyline (Vivactil)), Monoamine oxidase inhibitors (MAOIs: tranylcypromine (Parnate), phenelzine (Nardil) and isocarboxazid (Marplan)) and other medications such as such as mood stabilizers or antipsychotics all as well as anti-anxiety and stimulant medications. Many of these medications have their side effects. It could be however worthwhile to investigate the plant based principles to be used as more effective and safe chemotherapeutic compared to the currently used synthetic regimen.

\section{Acknowledgements}

Khushboo is grateful to UGC-New Delhi for financial support in the form of a fellowship.

\section{Conflict of interest}

The author declares no conflict of interest.

\section{References}

1. Salmans S. Depression: Questions You Have - Answers You Need. 1st ed. USA: People's Medical Society Paperback; 1995. 190 p.

2. Keller MB, Lavori PW, Rice J, et al. The persistent risk of chronicity in recurrent episodes of nonbipolar major depressive disorder: a prospective follow-up. Am J Psychiatry. 1986;143(1):24-28.

3. Mueller TI, Leon AC, Keller MB, et al. Recurrence after recovery from major depressive disorder during 15 years of observational follow-up. Am J Psychiatry. 1999;156(7):1000-1006.
4. Partonen T, Lönnqvist J. Seasonal affective disorder. Lancet. 1998;352(9137):1369-1374.

5. Doghramji K. Treatment strategies for sleep disturbance in patients with depression. J Clin Psychiatry. 2003;64(Suppl 14):24-29.

6. Leventhal AM, Rehm LP. The empirical status of melancholia: implications for psychology. Clin Psychol Rev. 2005;25(1):25-44.

7. Pillemer K, Suitor JJ, Pardo S, et al. Mothers' differentiation and depressive symptoms among adult Children. $J$ Marriage Fam. 2010;72(2):333-345.

8. Lindert J, Von Ehrenstein OS, Grashow R, et al. Sexual and physical abuse in childhood is associated with depression and anxiety over the life course: systematic review and meta-analysis. Int $J$ Public Health. 2014;59(2):359-372.

9. Schmidt PJ. Mood, depression, and reproductive hormones in the menopausal transition. Am J Med. 2005;118(Suppl 12B):54-58.

10. Rashid T, Heider I. Life Events and Depression. Pakistan: A Journal of Punjab Med College; 2008.

11. Vivek Kumar G, Sharma B. Modulations of mammalian brain functions by antidepressant drugs: role of some phytochemicals as prospective antidepressants. Evidence Based Medicine and Practice. 2016;1(3):1-12.

12. Standaert. Harvard-MIT Division of Health Sciences and Technology. Neuropharmacology II Antidepressants and Sedatives. USA; 2005. p. $1-8$

13. Bunney WE, Davis JM. Norepinephrine in depressive reactions. Arch Gen Psychiatry. 1965;13(6):483-494.

14. Heninger GR, Delgado PL, Charney DS. The revised monoamine theory of depression: A modulatory role for monoamines, based on new findings from monoamine depletion experiments in humans. Pharmacopsychiatry. 1996;29(1):2-11.

15. Schildkraut JJ. The catecholamine hypothesis of affective disorders: A review of supporting evidence. Am J Psychiatry. 19654;122(5):509522.

16. Anders Wessling, Joakim Ramsberg. The review of antidepressants Depression. 1st ed. Sweden: Dental and Pharmaceutical Benefits agenc; 2008. p. 1-112.

17. Goodman Louis S. Tricyclic Antidepressants. Goodman and Gilman's, the Pharmacological Basis of Therapentics. 8th ed. New York, USA: McGraw-Hill; 2000. p. 405-435.

18. Amitriptyline hydrochloride [package insert]. Trust Pharmacy, Broomfield, CO: Sandoz, USA: Inc; 2005.

19. Briggs GG, Freeman RK, Yaffe SJ. Drugs in Pregnancy and Lactation. 7th ed. Philadelphia, USA: Lippincott Williams \& Wilkins; 2005. 
20. Mourilhe P, Stokes PE. Risks and benefits of selective serotonin reuptake inhibitors in the treatment of depression. Drug Saf. 1998;18(1):57-82.

21. Modell JG, Katholi CR, Modell JD, et al. Comparative sexual side effects of bupropion fluoxetine, paroxetine, and sertraline. Clin Pharmacol Ther. 1997;61(4):476-487.

22. Tsirulnik-Barts L, Greenblatt DJ. Clinical pharmacology and therapeutics of antidepressants. In: Ciraulo DA, et al. editors. Pharmacotherapy of Depression. USA: Springer Science \& Business Media; 2011. p. 33-124.

23. Möller HJ, Volz HP. Drug Treatment of Depression in the 1990s. Drugs 1996;52(5):625-638.

24. Bleakley S. Review of the choice and use of antidepressant drugs. Prog Neurol Psychiatry. 2013;17(6):18-26.

25. Nierenberg AA, Alpert JE, Pava J, et al. Course and treatment of atypical depression. J Clin Psychiatry. 1998;59(Suppl 18):5-9.

26. Pande AC, Birkett M, Fechner-Bates S, et al. Fluoxetine versus phenelzine in atypical depression. Biol Psychiatry. 1996;40(10):1017-1020.

27. White K, Razani J, Cadow B, et al. Tranylcypromine vs nortriptyline vs placebo in depressed outpatients: a controlled trial. Psychopharmacology (Berl). 1984;82(3):258-262.

28. Darton K. Donate to Mind. UK: National Association for Mental Health; 2016.

29. http://www.mindinwestessex.org.uk/DocumentLibrary/Resources/ Making\%20Sense\%20of\%20Antidepressants.pdf

30. Stahl SM. Basic psychopharmacology of antidepressants, Part I: Antidepressants have seven distinct mechanisms of action. J Clin Psychiatry. 1998;59(Suppl 4):5-14

31. Richelson E. Pharmacology of antidepressants in use in the United States. J Clin Psychiatry. 1982;43(11 Pt 2):4-13.

32. DeMontigny C, Pineyro G, Chaput Y, et al. Electrophysiological studies on the effect of long-term 5-Ht Reuptake inhibition on the function of 5-HT Neurons. Clin Neuropharmacol. 1992;15(Suppl 1 Pt A):$440-441 \mathrm{~A}$

33. Blier P, DeMontigny C, Chaput Y. Modifications of the serotonin system by antidepressant treatments; implications for the therapeutic response in major depression. J Clin Psychopharmacol. 1987;7(6 Suppl):24-35S.

34. Foote SL, Morrison JH. Development of noradrenergic, serotonergic, and dopaminergic innervation of neocortex. Curr Top Dev Biol. 1987;21:391-423.

35. Baxter LR, Schwartz JM, Phelps ME, et al. Reduction of prefrontal cortex glucose metabolism common to three types of depression. Arch Gen Psychiatry. 1989;46(3):243-250.

36. Bersani G, Grispini A, Marini S, et al. 5-HT2 antagonist ritanserin in neuroleptic-induced parkinsonism: a double blind comparison with orphenadrine and placebo. Clin Neuropharmacol. 1990;13(6):500-506.

37. Stein DJ, Hollander E. Sexual dysfunction associated with the drug treatment of psychiatric disorders. CNS Drugs. 1994;2(1):78-86.

38. Balon R. The effects of antidepressants on human sexuality: Diagnosis and management update 1996. Primary Psychiatry. 1997;4:32-48.

39. Stahl SM. Remeron (mirtazapine): a novel antidepresssant that disinhibits serotonin and norepinephrine by alpha-2 antagonism. Psychiatric Annals. 1997;27:14-16.

40. Cooper BR, Wang CM, Cox RF, et al. Evidence that the acute behavioral and electrophysiological effects of bupropion (Wellbutrin) are mediated by a noradrenergic mechanism. Neuropsychopharmacology. 1994;11(2):133-141.
41. Casat CD, Pleasants DZ, Schroeder DH, et al. Bupropion in children with attention deficit disorder. Psychopharmacol Bull. 1989;25(2):198201.

42. Goldstein MG. Bupropion sustained release and smoking cessation. $J$ Clin Psychiatry. 1998;59(Suppl 4):66-72.

43. DeBattista C, Schatzberg AF. Other biological and pharmacological therapies. In: Sadock BJ, et al. editors. Comprehensive Textbook of Psychiatry. 7th ed. Philadelphia, USA: Lippincott Williams \& Wilkins; 2000. p. 2521-2531.

44. Lôo H, Deniker P. Position of tianeptine among antidepressive chemotherapies. Clin Neuropharmacol. 198;11(Suppl 2):S97-S102.

45. Defrance R, Marey C, Kamoun A. Antidepressant and anxiolytic activities of tianeptine: an overview of clinical trials. Clin Neuropharmacol. 1988;11(Supp1 2):S74-S82.

46. Ayflegül Yildiz, Ali Saffet Gönül, Lut Tamam. Mechanism of actions of antidepressants: beyond the receptors. Bulletin of Clinical Psychopharmacolog. 2002;12(4):194-200.

47. Lee $\mathrm{S}, \mathrm{Kim} \mathrm{DH}$, Lee $\mathrm{CH}$, et al. Antidepressant-like activity of the aqueous extract of Allium macrostemon in mice. $J$ Ethnopharmacol. 2010;131(2):386-395

48. Dhingra D, Kumar V. Evidences for the involvement of monoaminergic and GABAergic systems in antidepressant-like activity of garlic extract in mice. Indian J Pharmacol. 2008;40(4):175-179.

49. Mora S, Díaz-Véliz G, Millán R, et al. Anxiolytic and antidepressant-like effects of the hydroalcoholic extract from Aloysiapolystachya in rats. Pharmacol Biochem Behav. 2005;82(2):373-378.

50. Butterweck V, Nishibe S, Sasaki T, et al. Antidepressant effects of Apocynumvenetum leaves in a forced swimming test. Biol Pharm Bull. 2001;24(7):848-851.

51. Dar A, Khatoon S. Antidepressant effects of ethanol extract of areca catechu in rodents. Phytother Res. 1997;11(2):174-176.

52. Singh GK, Garabadu D, Muruganandam AV, et al. Antidepressant activity of Asparagus racemosus in rodent models. Pharmacol Biochem Behav. 2009;91(3):283-290

53. Sairam K, Dorababu M, Goel RK, et al. Antidepressant activity of standardized extract of Bacopamonniera in experimental models of depression in rats. Phytomedicine. 2002;9(3):207-211.

54. Kulkarni SK, Dhir A. On the mechanism of antidepressant-like action of berberine chloride. Eur J Pharmacol. 2008;589(1-3):163-172.

55. Kwon S, Lee B, Kim M, et al. Antidepressant-like effect of the methanolic extract from Bupleurumfalcatum in the tail suspension test. Prog Neuropsychopharmacol Biol Psychiatry. 2010;34(2):265-270.

56. Winterhoff $\mathrm{H}$, Spengler B, Christoffel V, et al. Cimicifuga extract BNO 1055: reduction of hot flushes and hints on antidepressant activity. Maturitas. 2003;44Suppl 1:S51-S58.

57. Jain NN, Ohal CC, Shroff SK, et al. Clitoriaternatea and the CNS. Pharmacol Biochem Behav. 2003;75(3):529-536.

58. Wang Y, Han T, Zhu Y, et al. Antidepressant properties of bioactive fractions from the extract of Crocus sativus L. J Nat Med. 2010;64(1):24 30

59. Yu ZF, Kong LD, Chen Y. Antidepressant activity of aqueous extracts of Curcuma longa in mice. J Ethnopharmacol. 2002;83(1-2):161-165.

60. Pemminati S, Gopalakrishna HN, Ashok K Shenoy, et al. Antidepressant activity of aqueous extract of fruits of Emblica officinalis in mice. International Journal of Applied Biology and Pharmaceutical Technology. 2010;1(2):449-454. 
61. Sakakibara H, Ishida K, Grundmann O, et al. Antidepressant effect of extracts from Ginkgo biloba leaves in behavioral models. Biol Pharm Bull. 2006;29(8):1767-1770.

62. Zhao Z, Wang W, Guo H, et al. Antidepressant-like effect of liquiritin from Glycyrrhizauralensis in chronic variable stress induced depression model rats. Behav Brain Res. 2008;194(1):108-113.

63. Dhingra D, Sharma A. Antidepressant-like activity of Glycyrrhizaglabra L. in mouse models of immobility tests. Prog Neuropsychopharmacol Biol Psychiatry. 2006;30(3):449-454.

64. Da Silva AF, De Andrade JP, Bevilaqua LR, et al. Anxiolytic-, antidepressant- and anticonvulsant-like effects of the alkaloid montanine isolated from Hippeastrum vittatum. Pharmacol Biochem Behav. 2006;85(1):148-154.

65. Sánchez-Mateo CC, Bonkanka CX, Prado B, et al. Antidepressant properties of some Hypericumcanariense L. and Hypericumglandulosum Ait.extracts in the forced swimming test in mice. J Ethnopharmacol. 2005;97(3):541-547.

66. Sánchez-Mateo CC, Bonkanka CX, Prado B, et al. Antidepressant activity of some Hypericumreflexum L. fil.extracts in the forced swimming test in mice. J Ethnopharmacol. 2007;112(1):115-121.

67. Wattanathorn J, Pangpookiew P, Sripanidkulchai K, et al. Evaluation of the Anxiolytic and Antidepressant effect of alcoholic extract of Kaempferiaparviflora in aged rats. American Journal of Agricultural and Biological Sciences. 2007;2(2):94-98.

68. Galdino PM, Nascimento MV, Sampaio BL, et al. Antidepressant-like effect of Lafoensiapacari A. St.-Hil.ethanolic extract and fractions in mice. J Ethnopharmacol. 2009;124(3):581-585.

69. Yi LT, Xu Q, Li YC, et al. Antidepressant-like synergism of extracts from magnolia bark and ginger rhizome alone and in combination in mice. Prog Neuropsychopharmacol Biol Psychiatry. 2009;33(4):616624.

70. Bhattamisra SK, Khanna VK, Agrawal AK, et al. Antidepressant activity of standardized extract of Marsileaminuta Linn. J Ethnopharmacol. 2008;117(1):51-57.

71. Molina M, Contreras CM, Tellez-Alcantara P. Mimosa pudica may possess antidepressant actions in the rat. Phytomedicine. 1999;6(5):319323 .

72. Idayu NF, Hidayat MT, Moklas MA, et al. Antidepressant-like effect of mitragynine isolated from MitragynaspeciosaKorth in mice model of depression. Phytomedicine. 2011;18(5):402-407.

73. Ganesan A, Natesan S, Perumal PG, et al. Anxiolytic, antidepressant and anti-inflammatory activities of methanol extract of momordica charantia linn leaves (Cucurbitaceae). Iranian Journal of Pharmacology and Therapeutics. 2008;7(1):43-47.

74. Zhang ZQ, Yuan L, Yang M, et al. The effect of Morindaofficinalis How, a Chinese traditional medicinal plant, on the DRL 72-s schedule in rats and the forced swimming test in mice. Pharmacol Biochem Behav. 2002;72(1-2):39-43.

75. Maity TK, Mandal SC, Saha BP, et al. Effect of Ocimum sanctum roots extract on swimming performance in mice. Phytother Res. 2000;14(2):120-121.
76. Mao Q, Huang Z, Ip S, et al. Antidepressant-like effect of ethanol extract from Paeonialactiflora in mice. Phytother Res. 2008;22(11):1496-1499.

77. Yao CY, Wang J, Dong D, et al. Laetispicine, an amide alkaloid from Piper laetispicum, presents antidepressant and antinociceptive effects in mice. Phytomedicine. 2009;16(9):823-829.

78. Cícero Bezerra Felipe F, Sousa Filho JT, De Oliveira Souza LE, et al. Piplartine, an amide alkaloid from Piper tuberculatum, presents anxiolytic and antidepressant effects in mice. Phytomedicine. 2007;14(9):605612 .

79. Capra JC, Cunha MP, Machado DG, et al. Antidepressant-like effect of scopoletin, a coumarin isolated from Polygala sabulosa (Polygalaceae) in mice: Evidence for the involvement of monoaminergic systems. Eur J Pharmacol. 2010;643(2-3):232-238.

80. Ali BH, Bashir AK, Tanira MO. The effect of rhazyastrictadecne, a traditional medicinal plant, on the forced swimming test in rats. Pharmacol Biochem Behav. 1998;59(2):547-550.

81. Machado DG, Bettio LE, Cunha MP, et al. Antidepressant-like effect of the extract of Rosmarinus officinalis in mice: involvement of the monoaminergic system. Prog Neuropsychopharmacol Biol Psychiatry. 2009;33(4):642-650.

82. Mora S, Millán R, Lungenstrass $\mathrm{H}$, et al. The hydroalcoholic extract of Salvia elegans induces anxiolytic- and antidepressant-like effects in rats. J Ethnopharmacol. 2006;106(1):76-81.

83. Machado DG, Bettio LE, Cunha MP, et al. Antidepressant-like effect of rutin isolated from the ethanolic extract from Schinusmolle L. in mice: Evidence for the involvement of the serotonergic and noradrenergic systems. Eur J Pharmacol. 2008;587(1-3):163-168.

84. Rodrigues AL, Da Silva GL, Mateussi AS, et al. Involvement of monoaminergic system in the antidepressant-like effect of the hydroalcoholic extracts of Siphocampylusverticillatus. Life Sci. 2002;70(12):13471358.

85. Galani VJ, Patel BG. Effect of hydroalcoholic extract of Sphaeranthusindicus against experimentally induced anxiety, depression and convulsions in rodents. Int J Ayurveda Res. 2010;1(2):87-92.

86. Freitas AE, Budni J, Lobato KR, et al. Antidepressant-like action of the ethanolic extract from Tabebuiaavellanedae in mice: evidence for the involvement of the monoaminergic system. Prog Neuropsychopharmacol Biol Psychiatry. 2010;34(2):335-343.

87. Guadarrama-Cruz G, Alarcon-Aguilar FJ, Lezama-Velasco R, et al. Antidepressant-like effects of Tageteslucida Cav. in the forced swimming test. J Ethnopharmacol. 2008;120(2):277-281.

88. Hattesohl M, Feistel B, Sievers H, et al. Extracts of Valeriana officinalis L. s.l. show anxiolytic and antidepressant effects but neither sedative nor myorelaxant properties. Phytomedicine. 2008;15(1-2):2-15.

89. Subhan F, Karim N, Gilani AH, et al. Terpenoid content of Valerianawallichii extracts and antidepressant-like response profiles. Phytother Res. 2010;24(5):686-691.

90. Bhattacharya SK, Bhattacharya A, Sairam K, et al. Anxiolytic-antidepressant activity of Withania somnifera glyco-withanolides: an experimental study. Phytomedicine. 2000;7(6):463-469. 